\title{
Location-Allocation Problems in the Perspective of Supply Chain: Approaches and Applications
}

\author{
Ilyas Masudin \\ Teknik Industri, Universitas Muhammadiyah Malang \\ Jalan Raya Tlogomas 246 Malang, Telp. 0341-464318 \\ E-mail: masudin@umm.ac.id
}

\section{ARTICLE INFO}

Article history

Received September 18, 2018

Revised November 12, 2018

Accepted January 21, 2019

Available Online February 14, 2019

Keywords

Supply chain

Location problem

Allocation

Approach

\begin{abstract}
This article attempts to explore approaches and applications of the location-allocation problems in the supply chain perspective. A review has been done for articles which have relation with the approach of location-allocation problems that includes the drivers of the supply chain such as inventory, transportation, service level, and customer demand. Moreover, the application of location-allocation problems that consider supply chain drivers is also discussed. In this article, a discussion of location-allocation discussions previously investigated by researchers is done through a literature review published in several reputable journal databases. 48 articles successfully collected and reviewed related approaches and applications used by researchers in location-allocation problems in a supply chain perspective. Analysis of the findings of this article can be summarized that approaches of the location-allocation problem in supply chain perspective can be divided into 2 areas: the echelon of the supply chain and the drivers of the supply chain.
\end{abstract}

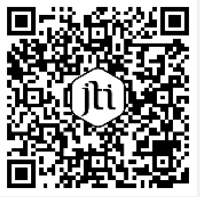

\section{Introduction}

In supply chain management, the movement and storage of the products and the lot sizing of the purchasing (quantity of the products) are categorized in the tactical planning level, which has medium-term planning decisions [1, 2]. To obtain better customer service, some activities in the physical distribution process consideration. Some activities included as order processing, storage decisions, inventory management, facility location and allocation decisions, transportations decisions and handling the returned product policy are the factors that included. Facility location-allocation decisions play a significant role in supply chain optimization. It is the indicator that there is a very clear connection among the decisions of facility location policy, allocation decisions and the strategic and tactical strategies in supply chain management operations. In other words, the decisions in determining facility location and strategy of allocating of the supply along the supply chain channel considering logistics drivers such as inventory management, transportation mode, and customer service policy hold an important role for the global competitiveness of the responsive and effective supply chain management strategy. 
In the context of logistics and supply chain management theory, the issues of facility location-allocation problems should be considered in the strategy of supply chain management. It is because 3 variables are affecting a successful supply chain management strategy. They are such as facility location decisions, the uncertain supply chain networks and production practice [3]. Furthermore, 3 primary elements in logistics management hold a significant role in the advance supply chain performance. They form a unique logistics system trade-offs that inter-relate each other and impact on the supply chain performance. They are facility location decisions, inventory, and transportation decisions $[3,4]$.

The study about location-allocation in the perspective of multi-echelon supply chain management previously is still limited, although previous study in location-allocation problems concern on mathematical modeling in the different approaches or methods applied in the various applications, however, most of them only consider location and allocation on their origin definition without considering any other components of logistics and supply chain. According to Melo, et al. [5] most of the location-allocation problem are discussed alone, while Şahin and Süral [6] found that $80 \%$ of location-allocation investigation in previous studies focused on the single echelon of the supply chain system. Thus, this article attempts to prove the investigation of the statement that researchers do not give most studies of location-allocation problems in perspective of supply chain management much attention by reviewing previous location-allocation studies. This article only focuses on the location-allocation problems in term of its applications and approaches.

\section{Methods}

The content analysis method is used in this article for reviewing literature. This method is used in some studies, and it is an approach to gather valid data by the purpose of providing new insights, comprehensive understanding for readers and researchers and managerial or practical actions. The method used in this study is based on existing literature publications that include: thesis, dissertations, and journal articles from different databases such as from Google Scholar, Scopus, Science direct and EBSCO host. Keywords like location, allocation, supply chain, inventory and transportation decisions were utilized to discover connected literature. Previous information that includes the subject of inventory control adopted in this study as the scholarly works published on the topic area is still inadequate. Thus, just literature written in English are examined in this study

The distribution of the selected publications form journals that discuss the problems of location-allocation study can be shown in Table 1 (supply chain drivers) and Table 2 (location-allocation approach). The literature in Table 1 and Table 2 were selected randomly without any limitation of the year published. However, it can be concluded that from 57 articles collected from the databases, 48 articles are discussing a locationallocation problem which considers in the perspective of supply chain drivers, locationallocation approach and the application of location-allocation problem in manufacturing and service industry.

\section{Literature Review}

\subsection{Location Decision and Supply Chain Management}

Material management and physical distribution activities are the main business processes that include related activities for a better customer service level. The activities 
are order processing, inventory management, facility location policy, distribution strategy and reverse logistics handling. Therefore, facility location decisions and also other logistics components such as inventory and transportation decisions play a critical role in designing an efficient supply chain through the distribution channels.

In the context of the supply chain, facility location issues should be included in supply chain decision making. There are three factors such as facility location, supply chain uncertainty and manufacturing practice that could impact on supply chain competitiveness [3]. Facility location properties as the cost of inventory and transportation, infrastructure and market effect significantly on the supply chain performance. Inventory and transportation decision are the most crucial properties of facility location decisions regarding optimizing a supply chain [7]. Moreover, some aspects of logistics as facility location decisions which are linked to inventory and transportation decisions are the important drivers to the success of supply chain competitiveness.

Table 1. The location-allocation problem considering supply chain drivers

\begin{tabular}{|c|c|c|c|c|c|}
\hline \multirow[b]{2}{*}{ Author } & \multicolumn{4}{|c|}{ Supply chain drivers } & \multirow[b]{2}{*}{ remark } \\
\hline & $\begin{array}{l}\text { Inventory } \\
\text { decisions }\end{array}$ & $\begin{array}{l}\text { Transporta- } \\
\text { tion decisions }\end{array}$ & $\begin{array}{l}\text { Infra- } \\
\text { structure }\end{array}$ & $\begin{array}{l}\text { Service } \\
\text { level }\end{array}$ & \\
\hline $\begin{array}{l}\text { Romeijn, et al. } \\
\text { [8] }\end{array}$ & $\sqrt{ }$ & $\sqrt{ }$ & & & $\begin{array}{l}\text { Transportation and } \\
\text { inventory decisions }\end{array}$ \\
\hline $\begin{array}{l}\text { Şahin and } \\
\text { Süral [6] }\end{array}$ & $\sqrt{ }$ & $\sqrt{ }$ & & & $\begin{array}{l}\text { Based on the } \\
\text { hierarchical flows }\end{array}$ \\
\hline $\begin{array}{l}\text { Diabat, et al. } \\
\text { [9] }\end{array}$ & $\sqrt{ }$ & & & & $\begin{array}{l}\text { Heuristics for location- } \\
\text { inventory problem }\end{array}$ \\
\hline $\begin{array}{l}\text { Hosseini and } \\
\text { Ameli [10] }\end{array}$ & & & & $\sqrt{ }$ & $\begin{array}{l}\text { Healthcare facility } \\
\text { problem }\end{array}$ \\
\hline $\begin{array}{l}\text { Diabat, et al. } \\
\text { [11] }\end{array}$ & & & & $\sqrt{ }$ & $\begin{array}{l}\text { mixed integer } \\
\text { nonlinear location- } \\
\text { allocation model }\end{array}$ \\
\hline $\begin{array}{l}\text { Avittathur, et } \\
\text { al. [12] }\end{array}$ & & $\sqrt{ }$ & $\sqrt{ }$ & & $\begin{array}{l}\text { Considering } \\
\text { transportation cost and } \\
\text { fixed facility cost }\end{array}$ \\
\hline Masudin [13] & $\sqrt{ }$ & $\sqrt{ }$ & $\sqrt{ }$ & $\sqrt{ }$ & $\begin{array}{l}\text { Considering } \\
\text { transportation, } \\
\text { inventory and service } \\
\text { level }\end{array}$ \\
\hline $\begin{array}{l}\text { Church and } \\
\text { ReVelle [14] }\end{array}$ & & $\sqrt{ }$ & & & $\begin{array}{l}\text { Transportation and } \\
\text { inventory decisions }\end{array}$ \\
\hline
\end{tabular}

In order to achieve a better performance of supply chain management, the combination of location and allocation problems in supply chain management drivers such as inventory decisions and transportation costs are crucial. Table 1 shows that most previous investigations about a location-allocation problem that considers supply chain drivers integrated inventory and transportation costs in the model. Comparing to the other studies that integrated supply chain's infrastructure (technology) and service level, inventory and transportation decisions are the most used in integrating location-allocation models. For instance, Hinojosa, et al. [15] made an interesting integration of their locationallocation model with inventory decisions in the multi-echelon supply chain network. The integrative design of their research involved another aspect of logistics such as inventory and found a better insight for supply chain context. Romeijn, et al. [8] developed a crucial framework of a location-allocation problem involving inventory costs in the model as well 
as transportation decisions in their two-echelon supply chain management network model and obtained an effective solution for two-echelon supply chain network. Moreover, $\mathrm{Ma}$ and Davidrajuh [16] combined the strategic and tactical supply chain networks into location-allocation model involving inventory and transportation strategy as a complex model.

\subsection{Approaches to Location-Allocation Problems in Supply Chain Environment}

Presently, the model of location-allocation problems has integrated the supply chain management environment in term of the echelon of the network model involved. The coordination along the distribution echelon of the supply chain has the objective to manage the inventory system, transportation decisions, and other supply chain drivers. The coordination from the channel of origin to the channel of consumption (retailers/customers) is the trending topic of the recent researchers in location-allocation model in the SCM context. Traditionally, most location-allocation studies used some approaches such as set covering problem, maximal covering problem, P-median, and Pcentre model (see Table 1). However, in term of the number of echelons considered in the model, it is found that most previous studies consider single echelon of the supply chain in their works. The use of a multi-echelon supply chain in the facility location-allocation model is limited. Most investigation of location-allocation studies that considering supply chain management environment involves transportation and inventory decisions in the model. While studies in a location-allocation problem that consider single echelon supply chain network commonly determine the facility location only, except a model for determining distribution centers considering the Central Sales Tax (CST) has been developed [12]. In his single-level location-allocation model, the distribution centers are determined in some states to satisfy retailer demand. Involving distribution and inventory strategy, the model is developed as a mixed integer programming with the objective of minimizing the total cost. Other researches model location-allocation problem in term of the single layer of distribution network such as [17-19]. Table 2 shows the approaches used in location-allocation problems in the supply chain environment.

Presently, the study considers a location-allocation problem which was applied in the supply chain environment has a high complexity in the multi-echelon system. For instance, a model of location-allocation problem in multi-echelon supply chain considering distribution and inventory costs in the different required service levels has been developed [20]. Moreover, research Romeijn, et al. [8] studied a two-echelon supply chain distribution network in which a supply of product is shipped from the supplier to distribution centers, then distributed to retailers. His two-echelon location-allocation model represents as a set covering model by integrating transportation and inventory decisions. The policy of single source distribution center in serving retailers is used to minimize the location and transportation costs as well as inventory costs.

\subsection{Application of Integrated Supply Chain Drivers into Location-Allocation Problem}

The location-allocation problem has the function to locate facilities in some alternatives locations as well as the number facility location opened. Consequently, the determined number of facilities and the determined location of facilities are also combined with the allocation of supply (products) from a facility to other facilities. The allocation of supplies is usually done from the upper downstream of the supply chain to downstream supply chains [21]. Recently, the issues in location-allocation problems considering multi- 
level distribution systems could increase another aspect significantly. In the problem of determining facility location sites, it is not only considering facility location geographically, but also involving other logistics aspects such as service level, inventory decisions, and transportation policy. The integration between facility location model with another aspect of logistics or supply chain management drivers is to approach proposed more realistic with the real system. Moreover, get the solution in integrative conditions, not separately. Prior research discussed the interdependence between location-allocation problem and inventory and transportation decisions as recommended by Perl and Sirisoponsilp [4] that location analysis should explicitly represent both inventory and transportation decisions.

Table 2. Location-allocation approaches in supply chain

\begin{tabular}{|c|c|c|c|c|c|c|c|}
\hline Author(s) & $\begin{array}{c}\text { Set } \\
\text { Covering }\end{array}$ & $\begin{array}{c}\text { Max } \\
\text { Covering }\end{array}$ & $\begin{array}{c}\mathrm{P}- \\
\text { Median }\end{array}$ & $\begin{array}{l}\text { Fixed } \\
\text { Charge }\end{array}$ & $\begin{array}{c}\mathrm{P}- \\
\text { centre }\end{array}$ & $\begin{array}{l}\text { Single } \\
\text { echelon }\end{array}$ & $\begin{array}{l}\text { Multi- } \\
\text { echelon }\end{array}$ \\
\hline Diabat, et al. [11] & & $\sqrt{ }$ & & & & $\sqrt{ }$ & \\
\hline Sule [22] & & & & $\sqrt{ }$ & & $\sqrt{ }$ & \\
\hline $\begin{array}{l}\text { Hanjoul and } \\
\text { Peeters [23] }\end{array}$ & & & $\sqrt{ }$ & & & $\sqrt{ }$ & \\
\hline $\begin{array}{l}\text { Nozick and } \\
\text { Turnquist [24] }\end{array}$ & & & & $\sqrt{ }$ & & $\sqrt{ }$ & \\
\hline $\begin{array}{l}\text { Suzuki and Drezner } \\
{[25]}\end{array}$ & & & & & $\sqrt{ }$ & $\sqrt{ }$ & \\
\hline $\begin{array}{l}\text { Nozick and } \\
\text { Turnquist [26] }\end{array}$ & & & & $\sqrt{ }$ & & & $\sqrt{ }$ \\
\hline Shen, et al. [7] & $\sqrt{ }$ & & & & & & $\sqrt{ }$ \\
\hline $\begin{array}{l}\text { Murray and } \\
\text { Gerrard [27] }\end{array}$ & $\sqrt{ }$ & & & & & $\sqrt{ }$ & \\
\hline Daskin [28] & & & $\sqrt{ }$ & & & $\sqrt{ }$ & \\
\hline $\begin{array}{l}\text { Bautista and } \\
\text { Pereira [29] }\end{array}$ & $\sqrt{ }$ & & & & & $\sqrt{ }$ & \\
\hline $\begin{array}{l}\text { Rahman and Smith } \\
\text { [30] }\end{array}$ & & & $\sqrt{ }$ & & & $\sqrt{ }$ & \\
\hline Jia, et al. [31] & & $\sqrt{ }$ & & & & $\sqrt{ }$ & \\
\hline Daskin [28] & & & & $\sqrt{ }$ & & & \\
\hline $\begin{array}{l}\text { Mahmud and } \\
\text { Indriasari [32] }\end{array}$ & & $\sqrt{ }$ & & & & $\sqrt{ }$ & \\
\hline $\begin{array}{l}\text { Avittathur, et al. } \\
{[12]}\end{array}$ & & & & $\sqrt{ }$ & & & \\
\hline Shen [17] & $\sqrt{ }$ & & & & & & \\
\hline $\begin{array}{l}\text { Sourirajan, et al. } \\
{[18]}\end{array}$ & & & & $\sqrt{ }$ & & & $\sqrt{ }$ \\
\hline $\begin{array}{l}\text { Barahona and } \\
\text { Jensen [33] }\end{array}$ & & & & $\sqrt{ }$ & & & \\
\hline Barros, et al. [34] & & & & $\sqrt{ }$ & & & \\
\hline
\end{tabular}

The facility location-allocation application that impact inventory decisions in the area of supply chain management have been discussed in the following ways. The increasing number of safety stock at the determined facility location would be impacted positively by the number of facilities operated. On the other words, the number of facility locations is opened the more safety stock provided on the site locations. Prior studies about 
the effects of facility location-allocation problems on the integration of supply chain drivers such as inventory management is proposed by Nozick and Turnquist [26]. Their study found that as the number of distribution facility increased, then the safety stock quantity also increases linearly. Moreover, Shen and Qi [35] investigated the high relationship between location-allocation problem and inventory decisions in a nonlinear integer programming and found that the relationship between location problem and inventory decisions is nonlinear in which when the inventory carrying costs goes up, the number of the facility opened goes down.

Moreover, in the application of location-allocation problem in the distribution system, the effect of transportation decision regarding the transportation mode and the size of shipment that related to the lot sizing model as discussed in the previous sections. The transportation mode and the size of shipment in which to provide a given service level will affect transportation decisions in choosing carriage and the transport routing with shorter lead times. The research by Shen and Qi [35] and Javid and Azad [36] investigated the impacts of transportation decisions in term of routing problems and found that the increase of the weight factor of inventory cost will increase the weight factor of transportation cost.

Transportation decisions in the distance traveled (transportation cost), size and frequency of shipment will affect the location decision in term of the facility establishment cost [37]. Melkote and Daskin [38] made an interesting investigation about the trade-off between transportation cost and investment budget. The transportation cost decreased as the investment budget increases, meanwhile the facility expenditure increase linearly to the budget. The other research by Temur, et al. [39] investigated the application of facility location problem in the reverse logistics environment as well as the study by Diabat, et al. [11] and Diabat, et al. [9]. They studied the use of location-allocation problem to determine the distribution centers that considering the returned products. A multi-echelon was used in their study in determining the proposed distribution and retail centers. The application of location-allocation problems with the integration of the supply chain drivers in different areas, it could be summarized in the following Table 3.

Table 3. The application of location-allocation problem that considers supply chain drivers

\begin{tabular}{ll}
\hline Applications & Author \\
\hline Healthcare & $\begin{array}{l}\text { Farahani, et al. [40], Chaiwuttisak, et al. [41], Gebicki, et al. [42], } \\
\text { Şahin, et al. [43] }\end{array}$ \\
\hline Public service & $\begin{array}{l}\text { Schuijbroek, et al. [44], Boyac1, et al. [45], Lin and Yang [46], } \\
\text { Usman, et al. [47] }\end{array}$ \\
\hline Supply chain network & $\begin{array}{l}\text { Randhawa and West [21], Perl and Sirisoponsilp [4], Acharya, et } \\
\text { al. [48], Govindan, et al. [49], Masudin [20]. }\end{array}$ \\
\hline Distribution system & $\begin{array}{l}\text { Nozick and Turnquist [26], Nozick and Turnquist [24], Shen and } \\
\text { Qi [35], Masudin [13], Wati and Nuha [50], Kusmindarti [51]. }\end{array}$ \\
\hline Reverse logistics & $\begin{array}{l}\text { Diabat, et al. [11], Diabat, et al. [9], Temur, et al. [39], Lu and } \\
\text { Bostel [52] }\end{array}$
\end{tabular}

\section{Discussions}

Location-allocation problems have been paid attention widely by researchers and practitioner in term of site selection decisions. There are the number of approaches used 
in the location-allocation problems such as set covering problem, maximal covering problems, fixed charge problems, and P-median problems. Most of the location-allocation problems are used to find the optimal number and location of the facility without considering any aspect of other disciplines. However, as the issues of inter-related discipline arise, presently the integration of location-allocation problem with other disciplines has been in a trending topic to determine the locational problems. One of the issues of location-allocation integration is the combination of logistics and supply chain disciplines. As the previous location-allocation model is used to determine only single echelon location of the facility [24, 26, 30], currently most studies of the location-allocation problem have been used to select facility location and allocation of supply considering two or more echelons of supply chain networks.

The model of location-allocation problem developed in multi-echelon supply chain networks also impact on the approaches used to solve the problems due to the more complicated chains and aspects. As the location-allocation problem is a part of NP-hard problems [53], so the more aspects and echelons added in the model would increase the degree of the difficulty to find the optimal solution in nondeterministic polynomial time. Thus, recent location-allocation studies that involving multi-echelon of supply chain networks and another aspect of logistics such as inventory and transportation decisions have varied approaches embedded into location-allocation model. Numerous new algorithms have been developed to solve these complicated combinations between locationallocation problems and logistics and supply chain disciplines recently. For instance, modified fruit fly optimization algorithms have been used to optimize location-allocation inventory problems in multi-echelon supply chain networks [54]. Other algorithms have been applied to solve location-allocation problem considering logistics and supply chain aspects such as multi-objective evolutionary approach [55], particle swarm optimization [56], a multi-objective harmony search algorithm [57].

In term of the application of location-allocation problems that apply the integration of logistics and supply chain aspects, it is clear that applications are adopted in different areas. As shown in Table 2, the adoption of the location-allocation problem that considers logistics and supply chain drivers are not only used for public service and healthcare that previously much-paid attention by researchers but also follow the trend of the research topic such as reverse logistics and supply chain management.

\section{Conclusion}

Most location-allocation studies previously discussed the problems related to the location selection and the decisions to allocate the required customers' demand. However, presently the progress of location-allocation studies also investigates the integration of the environment of supply chain management. The integration of inventory decisions, customer service level and transportation costs into the location-allocation problem are becoming the trend of the researcher's topic recently. The reviews indicate that most location-allocation studies recently consider the multi-channels of supply chain and the drivers of supply chain management such as inventory management, transportation decisions, infrastructure (technology) and market share. The review also indicates that the applications of the integration of location-allocation problems with the supply chain drivers have applied in the different areas such as healthcare, public facilities, distribution network, and manufacturing or service industries. The application of location-allocation problem considering logistics and supply chain aspects have grown the use of many algorithms to optimize the solution. The limitation of this article only discussed the location-allocation article published previously based on the content analysis. Thus, for 
further literature review study, the discussion could be expanded based on systematic or bibliometric analysis that focuses on the most cited and impacted literature on the location-allocation model for these two perspectives.

\section{References}

[1] T. Santoso, S. Ahmed, M. Goetschalckx, and A. Shapiro, "A stochastic programming approach for supply chain network design under uncertainty," European Journal of Operational Research, vol. 167, pp. 96-115, 2005/11/16/ 2005. https://doi.org/10.1016/j.ejor.2004.01.046

[2] S. H. Owen and M. S. Daskin, "Strategic facility location: A review," European Journal of Operational Research, vol. 111, pp. 423-447, 1998/12/16/ 1998. https://doi.org/10.1016/S0377-2217(98)00186-6

[3] R. Bhatnagar and A. S. Sohal, "Supply chain competitiveness: measuring the impact of location factors, uncertainty and manufacturing practices," $\begin{array}{lllll}\text { Technovation, } & \text { vol. } & 25, & \text { pp. } & 443-456,\end{array}$ https://doi.org/10.1016/j.technovation.2003.09.012

[4] J. Perl and S. Sirisoponsilp, "Distribution networks: facility location, transportation and inventory," International Journal of Physical Distribution \& Materials Management, vol. 18, pp. 18-26, 1988. https://doi.org/10.1108/eb014705

[5] M. T. Melo, S. Nickel, and F. Saldanha-Da-Gama, "Facility location and supply chain management-A review," European journal of operational research, vol. 196, pp. 401-412, 2009. https://doi.org/10.1016/j.ejor.2008.05.007

[6] G. Şahin and H. Süral, "A review of hierarchical facility location models," Computers \& Operations Research, vol. 34, pp. 2310-2331, 2007. https://doi.org/10.1016/j.cor.2005.09.005

[7] Z.-J. M. Shen, C. Coullard, and M. S. Daskin, "A joint location-inventory model,"

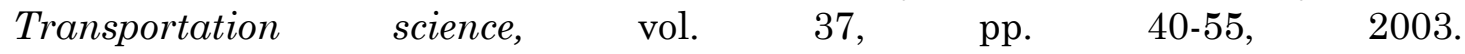
https://pubsonline.informs.org/doi/abs/10.1287/trsc.37.1.40.12823\#

[8] H. E. Romeijn, J. Shu, and C.-P. Teo, "Designing two-echelon supply networks," European Journal of Operational Research, vol. 178, pp. 449-462, 2007. https://doi.org/10.1016/j.ejor.2006.02.016

[9] A. Diabat, O. Battaïa, and D. Nazzal, "An improved Lagrangian relaxation-based heuristic for a joint location-inventory problem," Computers \& Operations Research, vol. 61, pp. 170-178, 2015. https://doi.org/10.1016/j.cor.2014.03.006

[10] M. Hosseini and M. Ameli, "A bi-objective model for emergency services locationallocation problem with maximum distance constraint," Management Science Letters, vol. 1, pp. 115-126, 2011. http://m.growingscience.com/msl/Vol1/ 20msl_2010_20.pdf

[11] A. Diabat, T. Abdallah, and A. Henschel, "A closed-loop location-inventory problem with spare parts consideration," Computers \& Operations Research, vol. 54, pp. 245-256, 2015. https://doi.org/10.1016/j.cor.2013.08.023

[12] B. Avittathur, J. Shah, and O. K. Gupta, "Distribution centre location modelling for differential sales tax structure," European Journal of Operational Research, vol. 162, pp. 191-205, 2005. https://doi.org/10.1016/j.ejor.2003.10.012

[13] I. Masudin, "Facility location modeling in multi-echelon distribution system: A case study of Indonesian Liquefied petroleum gas supply chain," Aceh International Journal of Science and Technology, vol. 2, pp. 37-43, 2013. https://doi.org/10.13170/aijst.2.1.595 
[14] R. Church and C. ReVelle, "The maximal covering location problem," in Papers of the Regional Science Association, 1974, pp. 101-118. https://doi.org/10.1007/BF01942293

[15] Y. Hinojosa, J. Kalcsics, S. Nickel, J. Puerto, and S. Velten, "Dynamic supply chain design with inventory," Computers \& Operations Research, vol. 35, pp. 373-391, 2008. https://doi.org/10.1016/j.cor.2006.03.017

[16] H. Ma and R. Davidrajuh, "An iterative approach for distribution chain design in agile virtual environment," Industrial Management \& Data Systems, vol. 105, pp. 815-834, 2005. https://doi.org/10.1108/02635570510607012

[17] Z.-J. M. Shen, "A profit-maximizing supply chain network design model with demand choice flexibility," Operations Research Letters, vol. 34, pp. 673-682, 2006. https://doi.org/10.1016/j.orl.2005.10.006

[18] K. Sourirajan, L. Ozsen, and R. Uzsoy, "A single-product network design model with lead time and safety stock considerations," IIE Transactions, vol. 39, pp. 411424, 2007. https://doi.org/10.1080/07408170600941631

[19] A. Marin and B. Pelegrín, "The return plant location problem: Modelling and resolution," European journal of operational research, vol. 104, pp. 375-392, 1998. https://doi.org/10.1016/S0377-2217(97)00192-6

[20] I. Masudin, "An Investigation of The Relationship Between Facility Location Decisions, Service Level and Distribution Costs: A Proposed Model Ffr Indonesian LPG Supply Chain," International Journal of Business \& Society, vol. 16, 2015. http://www.ijbs.unimas.my/repository/pdf/Vol16-no1-paper8.pdf

[21] S. U. Randhawa and T. M. West, "An integrated approach to facility location problems," Computers \& Industrial Engineering, vol. 29, pp. 261-265, 1995.

[22] D. R. Sule, "Simple methods for uncapacitated facility location/allocation problems," Journal of Operations Management, vol. 1, pp. 215-223, 1981. https://doi.org/10.1016/0272-6963(81)90027-9

[23] P. Hanjoul and D. Peeters, "A facility location problem with clients' preference orderings," Regional Science and Urban Economics, vol. 17, pp. 451-473, 1987. https://doi.org/10.1016/0166-0462(87)90011-1

[24] L. K. Nozick and M. A. Turnquist, "Integrating inventory impacts into a fixedcharge model for locating distribution centers," Transportation Research Part E: Logistics and Transportation Review, vol. 34, pp. 173-186, 1998. https://doi.org/10.1016/S1366-5545(98)00010-6

[25] A. Suzuki and Z. Drezner, "The p-center location problem in an area," Location science, vol. 4, pp. 69-82, 1996. https://doi.org/10.1016/S0966-8349(96)00012-5

[26] L. K. Nozick and M. A. Turnquist, "Inventory, transportation, service quality and the location of distribution centers," European Journal of Operational Research, vol. 129, pp. 362-371, 2001. https://doi.org/10.1016/S0377-2217(00)00234-4

[27] A. T. Murray and R. A. Gerrard, "Capacitated service and regional constraints in location-allocation modeling," Location science, vol. 5, pp. 103-118, 1997. https://doi.org/10.1016/S0966-8349(97)00016-8

[28] M. S. Daskin, "What you should know about location modeling," Naval Research Logistics (NRL), vol. 55, pp. 283-294, 2008. https://doi.org/10.1002/nav.20284

[29] J. Bautista and J. Pereira, "Modeling the problem of locating collection areas for urban waste management. An application to the metropolitan area of Barcelona," Omega, vol. 34, pp. 617-629, 2006. https://doi.org/10.1016/j.omega.2005.01.013

[30] S.-u. Rahman and D. K. Smith, "Use of location-allocation models in health service development planning in developing nations," ed: Elsevier, 2000. https://doi.org/10.1016/S0377-2217(99)00289-1 
[31] H. Jia, F. Ordóñez, and M. M. Dessouky, "Solution approaches for facility location of medical supplies for large-scale emergencies," Computers \& Industrial Engineering, vol. 52, pp. 257-276, 2007. https://doi.org/10.1016/j.cie.2006.12.007

[32] A. R. Mahmud and V. Indriasari, "Facility location models development to maximize total service area," Theoretical and Empirical Researches in Urban $\begin{array}{lllll}\text { Management, } & \text { vol. } & \text { 4, } & \text { 8p. }\end{array}$ https://www.jstor.org/stable/24872411?seq=2\#metadata_info_tab_contents

[33] F. Barahona and D. Jensen, "Plant location with minimum inventory," Mathematical Programming, vol. 83, pp. 101-111, 1998. https://doi.org/10.1007/BF02680552

[34] A. I. Barros, R. Dekker, and V. Scholten, "A two-level network for recycling sand: a case study," European journal of operational research, vol. 110, pp. 199-214, 1998. https://doi.org/10.1016/S0377-2217(98)00093-9

[35] Z.-J. M. Shen and L. Qi, "Incorporating inventory and routing costs in strategic location models," European journal of operational research, vol. 179, pp. 372-389, 2007. https://doi.org/10.1016/j.ejor.2006.03.032

[36] A. A. Javid and N. Azad, "Incorporating location, routing and inventory decisions in supply chain network design," Transportation Research Part E: Logistics and Transportation Review, vol. 46, pp. 582-597, 2010. https://doi.org/10.1016/j.tre.2009.06.005

[37] S. Sirisoponsilp, "Warehouse location under multiple transportation options," 1991.

[38] S. Melkote and M. S. Daskin, "An integrated model of facility location and transportation network design," Transportation Research Part A: Policy and Practice, vol. 35, pp. 515-538, 2001. https://doi.org/10.1016/S0965-8564(00)00005-7

[39] G. T. Temur, T. Kaya, and C. Kahraman, "Facility location selection in reverse logistics using a type-2 fuzzy decision aid method," in Supply chain management under fuzziness, ed: Springer, 2014, pp. 591-606. https://doi.org/10.1007/978-3-64253939-8_25

[40] R. Z. Farahani, M. Hekmatfar, B. Fahimnia, and N. Kazemzadeh, "Hierarchical facility location problem: Models, classifications, techniques, and applications," Computers \& Industrial Engineering, vol. 68, pp. 104-117, 2014. https://doi.org/10.1016/j.cie.2013.12.005

[41] P. Chaiwuttisak, H. Smith, Y. Wu, C. Potts, T. Sakuldamrongpanich, and S. Pathomsiri, "Location of low-cost blood collection and distribution centres in Thailand," Operations Research for Health Care, vol. 9, pp. 7-15, 2016. https://doi.org/10.1016/j.orhc.2016.02.001

[42] M. Gebicki, E. Mooney, S.-J. G. Chen, and L. M. Mazur, "Evaluation of hospital medication inventory policies," Health care management science, vol. 17, pp. 215229, 2014. https://doi.org/10.1007/s10729-013-9251-1

[43] G. Şahin, H. Süral, and S. Meral, "Locational analysis for regionalization of Turkish Red Crescent blood services," Computers \& Operations Research, vol. 34, pp. 692-704, 2007. https://doi.org/10.1016/j.cor.2005.03.020

[44] J. Schuijbroek, R. C. Hampshire, and W.-J. Van Hoeve, "Inventory rebalancing and vehicle routing in bike sharing systems," European Journal of Operational Research, vol. 257, pp. 992-1004, 2017. https://doi.org/10.1016/j.ejor.2016.08.029

[45] B. Boyacı, K. G. Zografos, and N. Geroliminis, "An optimization framework for the development of efficient one-way car-sharing systems," European Journal of Operational Research, vol. 240, pp. 718-733, 2015. https://doi.org/10.1016/j.ejor.2014.07.020 
[46] J.-R. Lin and T.-H. Yang, "Strategic design of public bicycle sharing systems with service level constraints," Transportation research part E: logistics and transportation review, vol. 47, pp. 284-294, 2011. https://doi.org/10.1016/j.tre.2010.09.004

[47] Y. V. Usman, A. H. Ismail, N. Y. Hidayah, and L. Chairani, "Pengembangan model pemilihan lokasi pembuangan akhir sampah perkotaan (Studi kasus: Kota Jakarta Timur)," 2013. http://hdl.handle.net/11617/3300

[48] N. Acharya, P. Mahat, and N. Mithulananthan, "An analytical approach for DG allocation in primary distribution network," International Journal of Electrical Power \& Energy Systems, vol. 28, pp. 669-678, 2006. https://doi.org/10.1016/j.ijepes.2006.02.013

[49] K. Govindan, A. Jafarian, R. Khodaverdi, and K. Devika, "Two-echelon multiplevehicle location-routing problem with time windows for optimization of sustainable supply chain network of perishable food," International Journal of Production Economics, vol. 152, pp. 9-28, 2014. https://doi.org/10.1016/j.ijpe.2013.12.028

[50] P. E. D. K. Wati and H. Nuha, "Pengembangan Model Capacitated Maximal Covering Location Problem (CMCLP) Dalam Penentuan Lokasi Pendirian Gudang," Jurnal Teknik Industri, vol. 19, pp. 21-27, 2018. https://doi.org/10.22219/JTIUMM.Vol19.No1.21-27

[51] D. Kusmindarti, "Penentuan Lokasi Distributor dengan Menggunakan Analytical Hierarchy Process dan Skala Liberatore," Jurnal Teknik Industri, vol. 10, pp. 1319, 2010. https://doi.org/10.22219/JTIUMM.Vol10.No1.13-19

[52] Z. Lu and N. Bostel, "A facility location model for logistics systems including reverse flows: The case of remanufacturing activities," Computers \& Operations Research, vol. 34, pp. 299-323, 2007. https://doi.org/10.1016/j.cor.2005.03.002

[53] G. Cornuéjols, G. Nemhauser, and L. Wolsey, "The Uncapicitated Facility Location Problem," Cornell University Operations Research and Industrial Engineering 1983.

[54] S. M. Mousavi, N. Alikar, S. T. A. Niaki, and A. Bahreininejad, "Optimizing a location allocation-inventory problem in a two-echelon supply chain network: A modified fruit fly optimization algorithm," Computers \& Industrial Engineering, vol. 87, pp. 543-560, 2015. https://doi.org/10.1016/j.cie.2015.05.022

[55] B. L. Shankar, S. Basavarajappa, J. C. Chen, and R. S. Kadadevaramath, "Location and allocation decisions for multi-echelon supply chain network-A multi-objective evolutionary approach," Expert Systems with Applications, vol. 40, pp. 551-562, 2013. https://doi.org/10.1016/j.eswa.2012.07.065

[56] S. M. Mousavi, A. Bahreininejad, S. N. Musa, and F. Yusof, "A modified particle swarm optimization for solving the integrated location and inventory control problems in a two-echelon supply chain network," Journal of intelligent manufacturing, vol. 28, pp. 191-206, 2017. https://doi.org/10.1007/s10845-0140970-z

[57] V. Hajipour, S. H. A. Rahmati, S. H. R. Pasandideh, and S. T. A. Niaki, "A multiobjective harmony search algorithm to optimize multi-server location-allocation problem in congested systems," Computers \& Industrial Engineering, vol. 72, pp. 187-197, 2014. https://doi.org/10.1016/j.cie.2014.03.018 